\title{
YIELD AND AGRONOMIC EFFICIENCY OF SUNFLOWER IN RESPONSE TO NITROGEN FERTILIZER APPLICATION AND SOWING SEASON ${ }^{1}$
}

\author{
RAFAEL DELGADO MARTÍNEZ ${ }^{2}$, WILBERTH ALFREDO POOT POOT ${ }^{3}$, SERGIO CASTRO NAVA ${ }^{2}$, MA TERESA \\ DE JESÚS SEGURA MARTÍNEZ ${ }^{4}$, MIGUEL EMILIO MORENO ORTEGA ${ }^{4}$
}

\begin{abstract}
Agronomic responses to the use of agricultural inputs have been used in agriculture to identify the optimal level of nutrients to be supplied for high yield. This strategy helps to avoid economic losses and excessive application of fertilizers that has caused pollution of aquifers and soil degradation. The aim of the study was to evaluate water use efficiency, agronomic efficiency of nitrogen, heat units and use of evapotranspiration in yield and its components in sunflowers under hot climate conditions in function of nitrogen fertilizer application during two sowing season. The experiment was conducted in the field. The treatments were two sowing seasons and three levels of nitrogen fertilizer application and one control: 0, 60, 80 and $120 \mathrm{~kg} \mathrm{~N} \mathrm{ha}^{-1}$. The nitrogen source was urea. The experimental design was complete random blocks with factorial array and four replications. The occurrence of cv. Cobalto sunflower phenological stages were not modified by the treatments. Urea favored agronomic efficiency and water use efficiency. Yield components were modified positively, with increasing receptacle area, 100-grain weight, and grain yield per receptacle. Application of nitrogen fertilizer favored sunflower development, although environmental conditions are of critical importance as demonstrated by a clear interaction between the yield response to fertilizer application and the environment where the plants grew.
\end{abstract}

Keywords: Water use efficiency. Agronomy efficiency. Yield. Evapotranspiration.

\section{PRODUÇÃO E EFICIÊNCIA AGRONOMICO DO GIRASSOL NA RESPOSTA À FERTILIZAÇÃO DE NITRÓGENO E À ÉPOCAS DE CULTIVO}

RESUMO - As respostas agronómicas ao uso dos insumos agrícolas, têm sido usados na agricultura para identificar o nível óptimo de fornecimento de nutrimentos para um alto rendimento, estratégia que ajuda a evitar perdas económicas, e a evitar o excessivo aplicativo de fertilizantes que têm provocado contaminação de mantos acuíferos e degradação do solos. O objetivo do estudo foi avaliar a eficiência no uso da água, eficiência agronômica do nitrogênio, unidades calor e uso da evapotranspiração no rendimento e componentes do rendimento de girassol em condições quentes em duas épocas de cultivo em função da fertilização de nitrógeno. Foi realizada no campo em condições experimentais. Os tratamentos consistiram em duas épocas e três níveis de aplicação de fertilização nitrogenada e um controle de 0,6080 e $120 \mathrm{~kg} \mathrm{~N} \mathrm{ha}^{-1}$, sendo usado como fonte de nitrogênio uréia. O delineamento experimental foi blocos completos randomizados, com arranjo fatorial e quatro repetições. A ocorrência de estádios fenológicos em cv de girassol. O cobalto não foi modificado pela aplicação de tratamentos. A aplicação de uréia, favoreceu a eficiência agronômica e eficiência no uso da água, modificou positivamente os componentes do rendimento aumentando a área do capítulo, o peso de 100 grãos e o rendimento de grãos por capítulo. A adubação nitrogenada se manifestou em favor do girassol, embora as condições ambientais sejam de importância crítica, como demonstrado em uma clara interação entre a resposta ao rendimento e a fertilização e o ambiente onde foi desenvolvido.

Palavras-chave: Eficiência no uso do água. Eficiência agronômica. Rendimiento. Evapotranspiração.

\footnotetext{
*Corresponding author

${ }^{1}$ Received for publication in $08 / 25 / 2017$; accepted in 03/26/2018.

Paper extracted from several experiments conducted by Department of Crop Ecophysiology.

${ }^{2}$ Department of Crop Ecophysiology, Universidade Autônoma de Tamaulipas, Victoria, TA, Mexico; rdelgado@docentes.uat.edu.mx ORCID: 0000-0001-9945-5985, scastro@docentes.uat.edu.mx - ORCID: 0000-0002-8759-001X

${ }^{3}$ Department of Crop Biotechnology, Universidade Autônoma de Tamaulipas, Victoria, TA, Mexico; wpoot@docentes.uat.edu.mx ORCID: 0000-0002-2973-3289.

${ }^{4}$ Faculty of Engineering and Sciences, Universidade Autônoma de Tamaulipas, Victoria, TA, Mexico; tsegura@docentes.uat.edu.mx ORCID: 0000-0001-8559-3885, emiliomoreno224@hotmail.com - ORCID: 0000-0003-2444-8814.
} 


\section{INTRODUCTION}

The sunflower crop is one of the most important oil crops in the world because of its quality (AHMAD et al., 2014; DALCHIAVON et al., 2016; PAPATHEOHARI et al., 2016), high protein content (AHMAD et al., 2014) and use of the different parts of the plant (SKORIC, 1992). Moreover, it is one of the energy crops that forms part of a reconversion and productivity improvement strategy for the countryside that is sustainable, mainly involving grain and oilseed production, mainly of grain and oilseed production.

However, the moderate production requirements (MOHAMMADI et al., 2013) and cultivation of this crop under rainfed conditions result in low yields, since the only source of water is rain, which is generally scarce (VALVERDE et al., 2015).

One problem of this type of cultivation is soil fertility, which is very limited because farmers normally apply little or no fertilizer. These restrictions in inputs result in great variation in yield, mainly linked to the quantity of rain during the biological cycle of a crop (GARCÍA et al., 2014). Moreover, farmers assume that irrigating a sunflower crop is not economically feasible and that water applied to other crops can generate more benefit (GARCÍA et al., 2016).

However, the effect of applying $\mathrm{N}$ on crop growth can be significantly limited by water availability, especially in semi-arid regions (SADRAS, 2004). Therefore, better understanding of the relationship between crop yield and $\mathrm{N}$ dosage could help to estimate the most adequate dosage of fertilizer for plants (GAO et al., 2012). Determination of an optimal level of nitrogen fertilizer is not an easy task since it depends on numerous factors, including the cultivar and the interactions among crop, environmental and agronomic factors (SZMIGIEL et al., 2016).

Improving nitrogen fertilizer use efficiency (NUE) is an option and a strategy commonly used as a parameter for improving sustainability of a crop, beyond increasing crop yields. It has been demonstrated that excess nitrogen fertilizers has adverse environmental impacts, such as $\mathrm{N}_{2} \mathrm{O}$ emissions and eutrophication of fresh water and marine ecosystems (SIELING; KAGE, 2008). However, if nitrogen use efficiency is not increased, reduced use of nitrogen fertilizers could decrease yields and crop quality if the plant undergoes $\mathrm{N}$ deficiency (CASSMAN et al., 2003).

The idea of improving NUE is not new (MOLL; KAMPRATH; JACKSON, 1982), but its importance as a strategy that can be easily implemented in a breeding program has not yet been recognized. Definitions of NUE and its features are abundant (HAN et al., 2015; CORMIER et al., 2016), but a widely accepted definition is the grain yield per unit of $\mathrm{N}$ supply in the soil since NUE involves different physiological processes, including absorption assimilation, translocation and remobilization (MASCLAUX-DAUBRESSE et al., 2010).

Nitrogen use efficiency, in its broadest sense, indicates how efficiently a plant is capable of capturing and using $\mathrm{N}$ to produce biomass or grain yield. NUE defined in this way is the product of the efficiency of $\mathrm{N}$ absorption (EAN) and efficiency of the use of $\mathrm{N}$ (EUN) (MOLL; KAMPRATH; JACKSON, 1982; NYIKAKO et al., 2014). NUE is described as the quantity of $\mathrm{N}$ acquired by the crop as a proportion of the available $\mathrm{N}$ in the soil, while efficiency of nitrogen use is given in units of grain yield per unit of acquired $\mathrm{N}$.

The objective of this study was to evaluate the water use efficiency, agronomic efficiency of nitrogen, heat units and use of evapotranspiration of sunflower yield and its components under hot conditions during two growing season in response to nitrogen fertilzer application.

\section{MATERIAL AND METHODS}

The study was conducted in an experimental field at the Facultad de Ingeniería y Ciencias of the Universidad Autónoma de Tamaulipas, located in Ciudad Victoria, Tamaulipas, Mexico (23 $42^{\prime} 52^{\prime \prime} \mathrm{N}$ and $99^{\circ} 9^{\prime} 12^{\prime \prime} \mathrm{W}, 327 \mathrm{~m}$ altitude). The climate is the least dry of the steppe climates; it is very hot with extreme summer temperatures of $40{ }^{\circ} \mathrm{C}$ (BSI(h') w' (e)). The soil of the area where the experiment was set up has a clayey texture, alkaline $\mathrm{pH}(8.1)$, very low inorganic nitrogen content $\left(4.59 \mathrm{mg} \mathrm{kg}^{-1}\right)$, electric conductivity of $0.56 \mathrm{dS} \mathrm{m}^{-1}$ and with no salinity problems. Sowing was performed manually on April 24, 2015 during the spring-summer season, and on August 25, 2015 in the autumn-winter season. Two or three sunflower seeds were deposited in each hole at a maximum depth of $4 \mathrm{~cm}$, with $30-\mathrm{cm}$ spacing between plants. Thirty days after sowing the plants were thinned to one plant. The seeds were Cobalt var. sunflower, a variety used in the study region, which were acquired from a commercial establishment.

To determine the climatic conditions during the experiment, data on average decennial high and low temperatures $\left({ }^{\circ} \mathrm{C}\right)$, precipitation $(\mathrm{mm})$ and decennial accumulated evaporation were obtained and the following phenological stages were recorded: V-E, emergence; V-2, first pair of true leaves; R-1, beginning of flowering; R-2, appearance of floral bud; R-5, open receptacle; R-6, drying petals; R-8, physiological maturity; R-9, commercial maturity. The criteria used to determine these variables were those of Schneiter And Miller (1981).

The treatments evaluated were two seasons and three application rates of nitrogen fertilizer plus 
control $\left(0,6080\right.$ and $\left.120 \mathrm{~kg} \mathrm{~N} \mathrm{ha}^{-1}\right)$. Urea was the nitrogen source. Before sowing, $50 \%$ of the nitrogen was applied, and the remaining $50 \%$ was applied at the second hoeing. Plant density was four plants $\mathrm{m}^{-2}$. The experimental design was complete random blocks, with a $4 \times 2$ factorial array, considering two factors (season and $\mathrm{N}$ rate) and four replications. Four treatments with four replications per treatment were established, giving a total of 16 experimental units. Each plot consisted of three rows $4 \mathrm{~m}$ long and $80 \mathrm{~cm}$ apart. The center row was the useful plot. When necessary, a single application of auxillary irrigation was used: surface irrigation was conducted along the rows for approximately one hour, endeavoring to maintain stable moisture conditions (field capacity). To prevent damage caused by weeds, manual weeding was performed when required.

Crop evapotranspiration (ETc) was calculated using the following equation:

$$
\mathrm{ETc}=\mathrm{De}^{*} \mathrm{Kc} * \mathrm{~Kb}(\mathrm{ALLEN} \text { et al., 2007) }
$$

Where:

$\mathrm{De}=$ daily evaporation $\left(\mathrm{mm} \mathrm{d}^{-1}\right)$

$\mathrm{Kc}=$ crop coefficient $\left(0.35 \mathrm{Kc}_{\text {initial }}, 1.15 \mathrm{Kc}_{\text {intermediate }}\right.$, $0.35 \mathrm{Kc}_{\text {final }}$ )

$$
\mathrm{Kb}=\text { depth coefficient }(0.7)
$$

Heat units ( $\left.\mathrm{HU},{ }^{\circ} \mathrm{C} \mathrm{d}^{-1}\right)$ were also calculated using the method of Snyder (1985):

$$
H U=\Sigma[((T m a ́ x+T m i ́ n) / 2)-T b]
$$

Where:

Tmax $=$ daily maximum temperature

Tmin $=$ daily minimum temperature

$\mathrm{Tb}=8^{\circ} \mathrm{C}$ base temperature for sunflower

At harvest, grain yield (GY) and its components, diameter of the receptacle (DR), area of the receptacle (AR), grain weight per receptacle (GWR), and hundred grain weight $(100 \mathrm{GW})$, were recorded. A sample was collected to determine grain $\mathrm{N}$ content.

Water use efficiency was measured by dividing grain production, or economic yield, by crop evapotranspiration (WUE, $\mathrm{g} \mathrm{m}^{-2} \mathrm{~mm}^{-1}$ ):

$$
\mathrm{WUE}=\mathrm{GY} / \mathrm{ETc}
$$

Where:

$\mathrm{GY}=$ grain yield $\left(\mathrm{g} \mathrm{m}^{-2}\right)$

$\mathrm{ETc}=$ crop evapotranspiration $\left(\mathrm{mm}^{-1}\right)$

Agronomic efficiency (AE), considered as the increase in economic yield of a crop per unit of applied fertilizer, is an indicator of the plant's capacity to increase grain yield in response applied $\mathrm{N}$. This was calculated using the following equation:

$$
\operatorname{AE}\left(\mathrm{kg} \mathrm{kg}^{-1}\right)=\left(\mathrm{Y}_{\mathrm{F}}-\mathrm{Y}_{\mathrm{C}}\right) / \mathrm{F}
$$

Where:

$\mathrm{Y}_{\mathrm{F}}=$ grain yield of the fertilized crop

$\mathrm{Y}_{\mathrm{C}}=$ control (without fertilizer) grain yield

$\mathrm{F}=$ amount of fertilizer applied

Apparent recovery (RA) reflects the general efficiency with which $\mathrm{N}$ is applied and was calculated as:

Where:

$$
\operatorname{RA}(\%)=\left[\left(\mathrm{N}_{\mathrm{F}}-\mathrm{N}_{\mathrm{C}}\right) / \mathrm{F}\right] \times 100
$$

$\mathrm{N}_{\mathrm{F}}=\mathrm{N}$ content in grain of fertilized crop $\mathrm{N}_{\mathrm{T}}=\mathrm{N}$ content in grain of crop without fertilizer (control)

$$
\mathrm{F}=\text { amount of fertilizer applied. }
$$

Physiological efficiency (PE) can be seen as the efficiency with which the crop uses $\mathrm{N}$ absorbed by the plant for synthesis, for grain yield and protein.

Where:

$$
\mathrm{PE}\left(\mathrm{kg} \mathrm{kg}^{-1}\right)=\left(\mathrm{GY}_{\mathrm{F}}-\mathrm{GYc}\right) /\left(\mathrm{N}_{\mathrm{F}}-\mathrm{N}_{\mathrm{C}}\right)
$$

$\mathrm{PE}=$ physiological efficiency $\left(\mathrm{kg} \mathrm{kg}^{-1}\right)$

$\mathrm{GY}_{\mathrm{F}}=$ grain yield of the fertilized crop

$\mathrm{GYc}=$ grain yield of the control (without fertilizer)

$\mathrm{N}_{\mathrm{F}}=\mathrm{N}$ content in grain of the fertilized crop

$\mathrm{N}_{\mathrm{C}}=\mathrm{N}$ content in grain of crop without fertilizer (control)

An analysis of variance (ANOVA) was applied to the evaluated variables, using SAS 9.1 statistical software, and mean values were compared with the Tukey test $(\mathrm{P} \leq 0.05)$. Relationships between variables were examined by linear regression analysis.

\section{RESULTS AND DISCUSSION}

The sunflower crop season varies depending on the earliness of the crop (from 120 to 150 days) and the type of climate. In this study using cv. Cobalt sunflower, occurrence of the phenological stages was not modified by application of the nitrogen fertilizer treatments.

It was, however, conditioned by the oscillation of climate elements (Figure 1) during the two seasons. In both seasons, the crop cycle was 120 days. In a semi-arid region in which the $\mathrm{N}$ required by the crops may be low (according to global standards) and where water is an important driver of productivity, there may be advantages to a better correspondence between the supply and the potential yield. In this sense, Nasim et al. (2016) reported that the variation in environmental conditions affects growth and development of the sunflower despite its adaptability to different types of soil and climates (CASTRO; FARIAS, 2005). Moreover, Sposaro, Chimenti and Hall (2008) noted that sunflowers are 
highly sensitive to the sowing date and management practices, which are affected by local climate and soil factors.

Precipitation fluctuated considerably (3 to $103 \mathrm{~mm}$ in S-S and 5 to $115 \mathrm{~mm}$ in A-W) (Figure 1a and 1b), possibly causing changes in crop development since during the reproductive stage there was little or no rainfall $\left(2^{\text {nd }}\right.$ and $3^{\text {rd }}$ week of July in the S-S season and $1^{\text {st }}$ and $3^{\text {rd }}$ week of November in the A-W season). In addition, evaporation was higher than the available water, mainly because of the high rates of evaporation (74 $\mathrm{mm}$ ) during the flowering stage (R-5) caused by high temperature $\left(39^{\circ} \mathrm{C}\right)$ in the $\mathrm{S}-\mathrm{S}$ season. This possibly caused decreases in the production of biomass, affecting or decreasing crop yield (Figure 1a). Similarly, Rondanini, Savin and Hall (2003) reported that prolonged periods of high temperature during the period of grain fill invariably leads to low achene yield. For this reason, in some situations, there are strong individual effects of environmental factors.

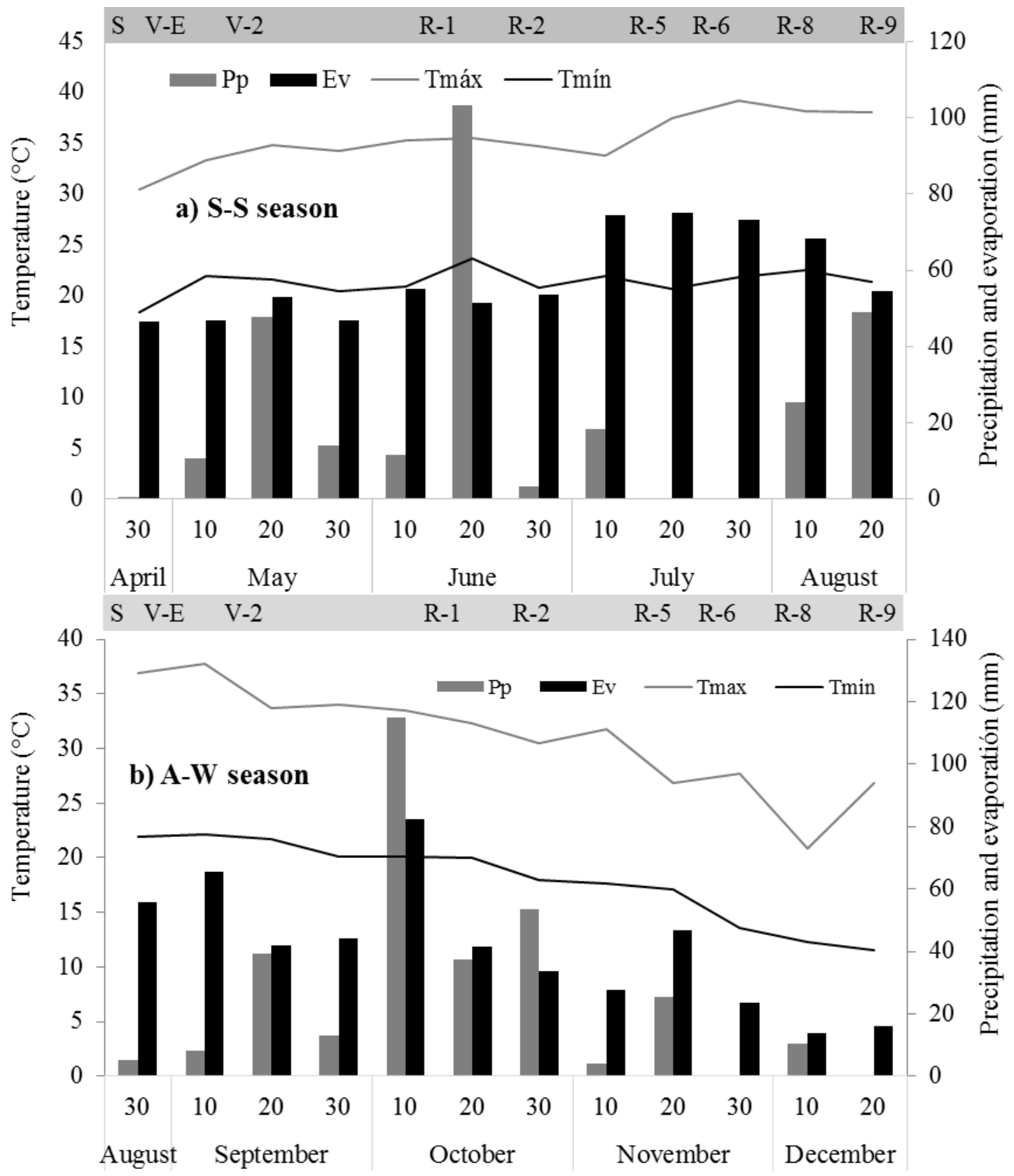

Figure 1. Phenology, total precipitation (PP) and (Ev) for each 10-day, and average value of maximum (Tmax) and minimum (Tmin) temperature in sunflower cv. Cobalto. a) S-S season (spring-summer 2015) and b) A-W season (autumnwinter 2015). S: sow; V-E, emergence; V-2, first pair of true leaves; R-1, beginning of flowering; R-2, appearance of floral bud; R-5, open receptacle; R-6, drying petals; R-8, physiological maturity; R-9, commercial maturity. 
Battisti and Naylor (2009) indicated that the combination of water deficit and heat stress has profound implications for food security because of its effect on crop growth and water use.

Accumulation of heat units (HU), as the heat required by the crop to develop, and accumulated evapotranspiration (ETc), as the amount of water a crop needs to grow over its entire cycle, are presented in Figure 2.

The heat requirement of sunflower plants varied with the season and phenological stage of the crop. In the S-S season, $181 \mathrm{HU}$ were required for the V-E stage, $380 \mathrm{HU}$ were necessary for $\mathrm{V}-2$, and $900 \mathrm{HU}$ for R-1. To arrive at R-8, $2000 \mathrm{HU}$ were necessary, and to complete its development and arrive at commercial maturity, $2400 \mathrm{HU}$ were needed.

Evapotranspiration of sunflower (ETc), or water required by the crop to reach commercial maturity, was $400 \mathrm{~mm}$, distributed over each stage. Two forms over the cycle were required for both evaporation and transpiration. For V-2, it was $24 \mathrm{~mm}$ because in this developmental stage the plant canopy is limited. It is estimated that most of the ETc, or water consumption, is evaporation directly from the soil. At R-1 (beginning of flowering), ETc increased $31 \%(125 \mathrm{~mm})$ relative to the total, consuming 400 $\mathrm{mm}$ over the entire cycle. Moreover, it was observed that the accumulation of HU and ETc during the crop season showed a linear increase' with changes of 20 ${ }^{\circ} \mathrm{C}$ and $3.7 \mathrm{~mm}$ per day from $\mathrm{S}$ to $\mathrm{R}-9$.
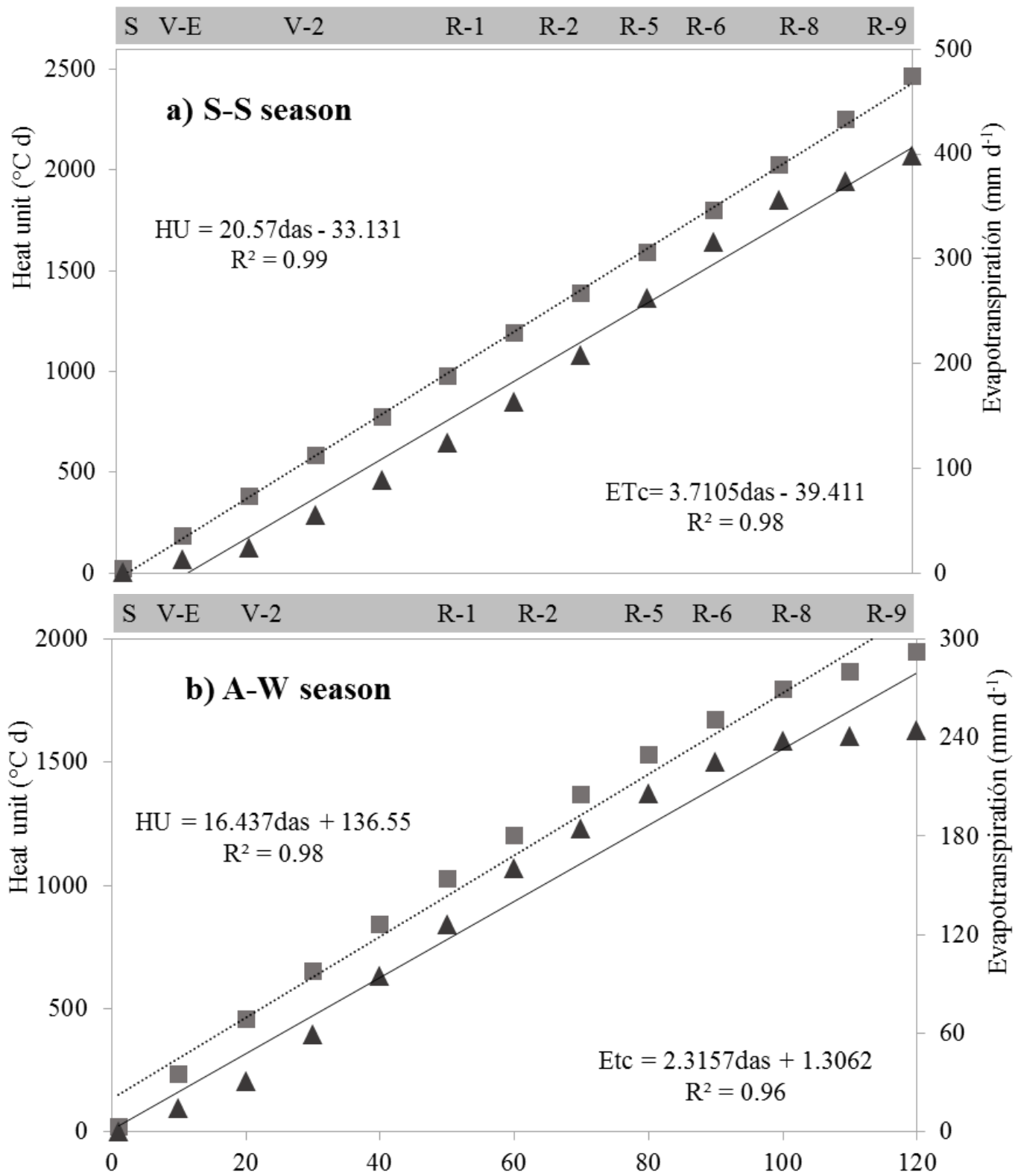

Figure 2. Heat unit and accumulated evapotranspiration in sunflower cv. Cobalto. a) S-S season (spring-summer 2015) and b) A-W season (autumn-winter 2015). S: sow; V-E, emergence; V-2, first pair of true leaves; R-1, beginning of flowering; R-2, appearance of floral bud; R-5, open receptacle; R-6, drying petals; R-8, physiological maturity; R-9, commercial maturity. 
The analysis of variance indicates that the rates of $\mathrm{N}$ application, the season and the interaction of these two factors significantly affected $(\mathrm{P} \leq 0.05)$ grain yield, receptacle diameter, receptacle area, grain weight per receptacle, hundred grain weight, agronomic nitrogen efficiency, and water use efficiency (Table 1). The yield data for different levels of $\mathrm{N}$ were positive and highly significant differences for the two seasons. The highest values of the variables evaluated resulted from application of $120 \mathrm{~kg} \mathrm{~N} \mathrm{ha}^{-1}$ during the A-W season (Figure 3a and $3 b)$.

The relationship between the high level of $\mathrm{N}$ and the season cycle was strongly related to the relative humidity in both cycles. Regarding the effect of nitrogen fertilizer application, an increase in GY of up to $86 \%$ was obtained when $\mathrm{N}$ was supplied $\left(120 \mathrm{~kg} \mathrm{~N} \mathrm{ha}^{-1}\right)$ relative to the control $\left(0 \mathrm{~kg} \mathrm{~N} \mathrm{ha}^{-1}\right)$ and an increase of $10 \%$ relative to the season, as a consequence of the increase in DR and AR, and in GWR and, therefore, in 100GW. Sunflower growth and yield is related mostly to the availability of diverse nutrients. Of these nutrients, nitrogen is of crucial importance for sunflower production, having a positive effect (AWAIS et al., 2017) on each of the yield components and on yield itself by increasing the photosynthetic rate, which depends on nitrogen (ROUPHAEL et al., 2007), and thus increasing the total nitrogen content in leaves, while increasing leaf area and plant height (VOS; VAN DER PUTTEN; BIRCH, 2004).

Table 1. Analysis of variance for the variables grain yield (GY), yield components (DR, diameter of receptacle; AR, area of receptacle; 100GW, 100 grain weight; GWR, grain weight per receptacle), nitrogen use efficiency (NUE) and water use efficiency (WUE).

\begin{tabular}{|c|c|c|c|c|c|c|c|}
\hline Source of variation & $\begin{array}{c}\mathrm{GY} \\
\mathrm{g} / \mathrm{m}^{-2}\end{array}$ & $\begin{array}{l}\text { DR } \\
\mathrm{cm}\end{array}$ & $\begin{array}{l}\text { AR } \\
\mathrm{cm}^{-2}\end{array}$ & $\begin{array}{c}\text { GWR } \\
\text { g }\end{array}$ & $\begin{array}{c}00 \mathrm{G} \\
\mathrm{g}\end{array}$ & $\begin{array}{c}\text { NUE } \\
\mathrm{g} \mathrm{g}^{-1} \mathrm{~N}\end{array}$ & $\begin{array}{c}\text { WUE } \\
\mathrm{g} \mathrm{m}^{-2} \mathrm{~mm}\end{array}$ \\
\hline Season (S) & $* *$ & $* *$ & $* *$ & $* *$ & $* *$ & $* *$ & $* *$ \\
\hline $\mathrm{N}$ rates $(\mathrm{R})$ & $* *$ & $* *$ & $* *$ & $* *$ & $* *$ & $* *$ & $* *$ \\
\hline S X R & $* *$ & $* *$ & $* *$ & $* *$ & $* *$ & $* *$ & $* *$ \\
\hline $\mathrm{CV}(\%)$ & 20 & 25 & 20 & 22 & 14 & 25 & 26 \\
\hline
\end{tabular}

*, ** Significant differences $\mathrm{P}>0.05$ and 0.01 , respectively. NS $=$ non significant difference.

Sunflower yield increased with the application of $\mathrm{N}$ in both seasons; positive differences were detected when $\mathrm{N}$ increased. Yield increased approximately $53 \%$ with $120 \mathrm{~kg} \mathrm{ha}^{-1} \mathrm{~N}$. Variation in yield caused by supplying $\mathrm{N}$ was great considering all the results of all the experiments, but the biggest variation in response occurred when $\mathrm{N}$ was not applied (control). In this sense, optimal fertilizer application is essential to maintaining soil fertility and stabilizing crop yield. WUE is favored by supplying $\mathrm{N}$, but a marked difference between cycles was observed higher during the A-W season $(55 \%$, $\left.0.99 \mathrm{~g} \mathrm{~m}^{-2} \mathrm{~mm}\right)$. Regarding application of $\mathrm{N}$, the highest values of WUE were found when $120 \mathrm{~kg} \mathrm{ha}^{-1}$ $\mathrm{N}$ was applied, in both seasons. For the S-S season, the increase was $52 \%$ for the highest level (120 kg ha $\left.{ }^{-1} \mathrm{~N}\right)$ relative to the control $\left(0 \mathrm{~kg} \mathrm{ha}^{-1} \mathrm{~N}\right)$. In the A-W season, the increase was $51 \%$ when the highest dosage of $\mathrm{N}$ was applied. In this sense, LópezBellido et al. (2006) report that by applying $\mathrm{N}$ during specific growth stages, or strategic $\mathrm{N}$ application, even when precipitation is far below average, it is possible to manipulate the size of the canopy and water use during the growing season. This would permit a better combination of water supply, crop growth and $\mathrm{N}$ demand. Similar to precipitation, fertilizer application significantly affects sunflower yields. In general, more rain falls during the first growth stages and less in the last growth period, the reproductive stage, and dependence on accumulated moisture during the crop's growing cycle becomes increasingly important for crop growth and yield as the season progresses (RIAR; COVENTRY, 2013).

Moreover, EAN increases economic yield of a crop per unit of applied fertilizer. Apparent recovery (RA) and physiological efficiency (PE) of $\mathrm{N}$ are indexes that can help to improve efficiency by indicating the amount of fertilizer the crops need. Thus, the crop makes better use of the fertilizer and, consequently, certain yield components are modified positively, namely DR, AR, GWR and 100GW.

EAN, RA, PE (Figure 4) showed significant changes with $\mathrm{N}$ supply, season and their interaction. EAN increased, with the highest $\mathrm{N}$ values $(50 \%)$ relative to the control. Also, with regard to the season, the highest EAN was observed during the AW season, which was $15 \%$ higher than in the $\mathrm{S}-\mathrm{S}$ season. In the case of RA, the changes were more notable; a higher percentage of recovery was observed when $60 \mathrm{~kg} \mathrm{ha}^{-1} \mathrm{~N}(44 \%)$ was applied 
compared with $17 \%$ with $120 \mathrm{~kg} \mathrm{ha}^{-1} \mathrm{~N}$. At the highest rate of $\mathrm{N}$ application, apparent recovery was limited to $<45 \%$. Apparent recovery improved with lower rates of $\mathrm{N}$, meaning that grain $\mathrm{N}$ content was similar to that achieved with higher $\mathrm{N}$ rates, which had far lower rates of recovery. The data suggest that applications of high $\mathrm{N}$ rates can significantly increase absorption of $\mathrm{N}$ fertilizer.
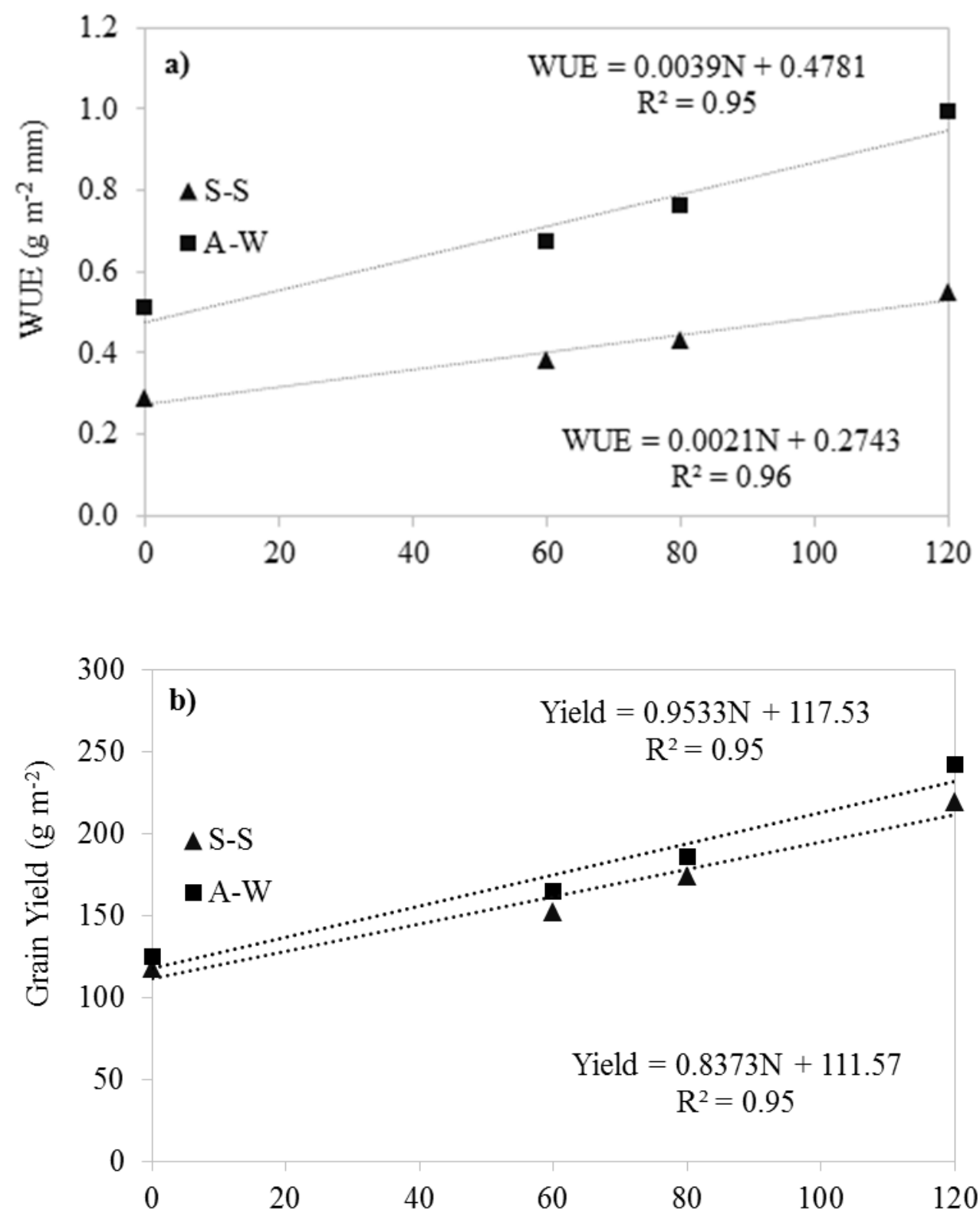

Figure 3. a) Grain yield and b) Water use efficiency (WUE) in sunflower cv. Cobalto with different nitrogen application rates in the S-S season (spring-summer 2015) and A-W season (autumn-winter 2015). 

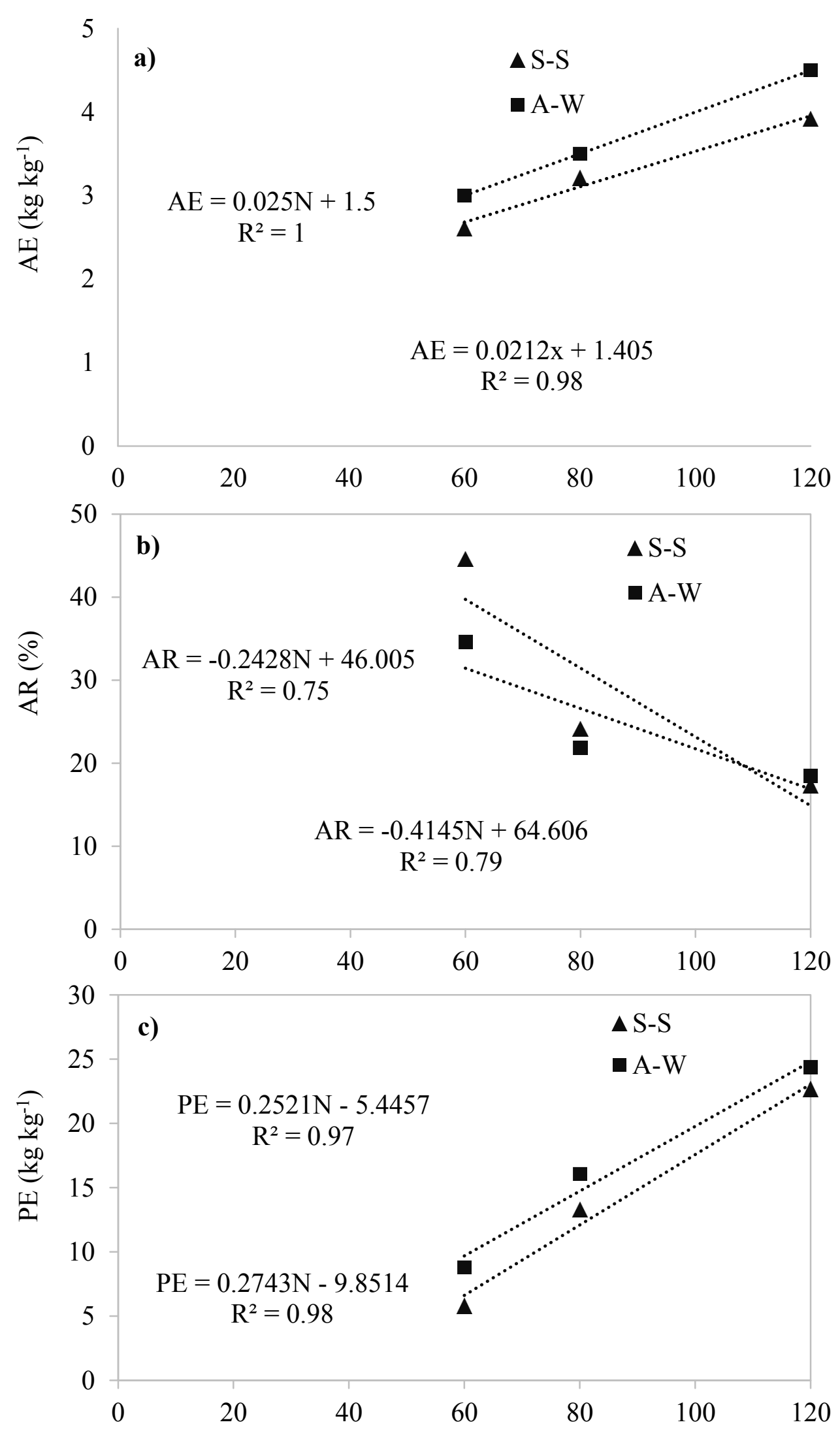

Figure 4. a) Agronomy efficiency (AE), b) Apparent recovery (AR) and c) Physiological efficiency (PE) in sunflower cv. Cobalto, with different nitrogen application rates in the S-S season (spring-summer 2015) and A-W season (autumn-winter 2015). 
The values of physiological efficiency $(\mathrm{PE})$ were generally low, although the variation between treatments was evident. For PE, the increases were observed with the highest values of $\mathrm{N}$ supply. Likewise, with regard to the season, it was observed that PE was higher in A-W than in S-S. Physiological efficiency increased with high rates of $\mathrm{N}$ compared with application of low rates, similar to the results of López-Bellido et al. (2006). The data suggest that at high rates, the $\mathrm{N}$ applied is used efficiently by the crop. The balance between apparent recovery and physiological efficiency, indicated by the negative correlation between the two, was possibly because the plant uses $\mathrm{N}$ more efficiently when it does not use a large portion of the N.

The higher the yield, the better the WUE, with respect to the level of $\mathrm{N}$. This can be seen in Figure 5, which shows the comparison between seasons $(5 \mathrm{a}, 5 \mathrm{~b})$ and the amount of nitrogen in terms of yield and WUE. For the S-S season, sunflower yield showed a positive relationship with levels of $\mathrm{N}$, reflected by a high coefficient of determination $\left(\mathrm{R}^{2}=\right.$ 0.95 ) and the fit of the model (yield $=0.8373 \mathrm{~N}+$ 111.57), which was linear for both yield and WUE. The equation describes the optimum application of fertilizer for the highest $\mathrm{N}$ values $\left(120 \mathrm{~kg} \mathrm{~N} \mathrm{ha}^{-1}\right)$, returning to the trend that the higher the supply of nitrogen fertilizer, the higher the yield and the higher the WUE.

For the A-W season, the supply of $\mathrm{N}$ to the crop increased yield and WUE equally. With $120 \mathrm{~kg}$ $\mathrm{ha}^{-1} \mathrm{~N}$, yield and WUE were $242 \mathrm{~g} \mathrm{~m}^{-2}$ and $0.99 \mathrm{~g} \mathrm{~m}^{-}$ ${ }^{2} \mathrm{~mm}$, respectively (Figure $5 \mathrm{~b}$ ). The equation that describes this relationship was linear, with an optimum application of $120 \mathrm{~kg} \mathrm{ha}^{-1} \mathrm{~N}$ and a significant coefficient of determination $\left(R^{2}=0.95\right)$.

$$
\text { Nitrogen rates }\left(\mathrm{kg} \mathrm{ha}^{-1}\right)
$$
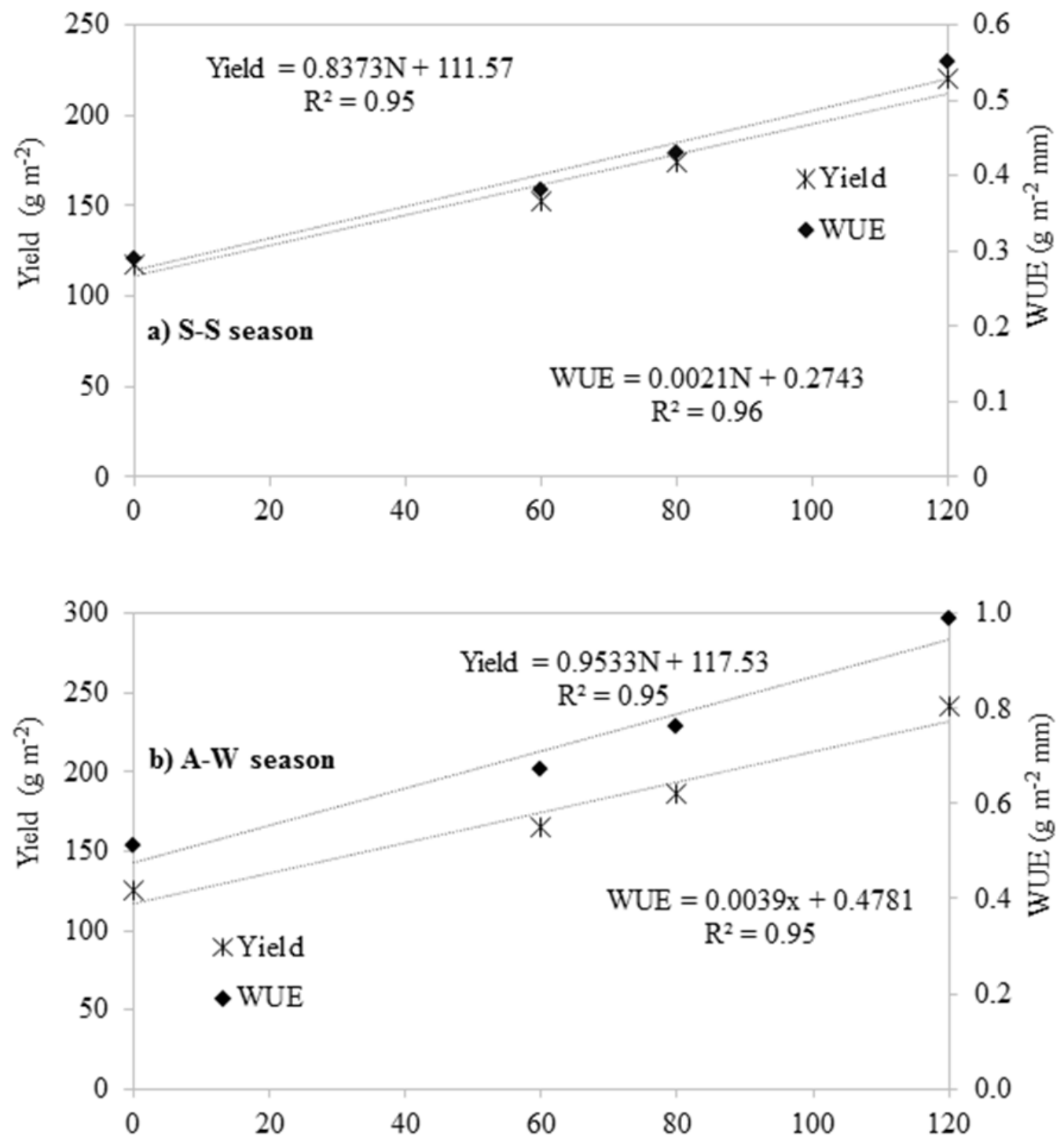

Figure 5. Yield and water use efficiency of sunflower crop, as a function of different nitrogen application rates applied during the a) S-S season (spring-summer 2015) and b) A-W season (autumn-winter 2015). 


\section{CONCLUSIONS}

The nitrogen rates used under hot conditions in two sowing season positively affected the water use efficiency, agronomic efficiency of nitrogen, heat units and use of evapotranspiration in terms of sunflower yield and its components.

Application of nitrogen fertilizer favored the sunflower crop, although the environmental conditions are of critical importance as demonstrated by the clear interaction between the yield response to fertilizer application and the season in which this occurred.

The NUE index was shown to be an excellent tool for determining the effectiveness of nitrogen fertilizer application in crops. Based on the results of this study, an application rate for $\mathrm{N}$ fertilizer of approximately $120 \mathrm{~kg} \mathrm{ha}^{-1}$ in hot climates during the $\mathrm{A}-\mathrm{W}$ season is recommended as the most favorable.

\section{ACKNOWLEDGEMENTS}

The authors thank PROMEP Mexico for the support granted to the first author as a new full-time professor at the Universidad Autónoma de Tamaulipas.

\section{REFERENCES}

ALLEN, G. R. et al. Evapotranspiración del cultivo. Guías para la determinación de los requerimientos de agua de los cultivos. Estudio FAO. Riego y Drenaje. Manual 56. RM. ITALIA. 2007. 298 p.

AHMAD, R. et al. Does nitrogen fertilization enhance drought tolerance in sunflower? A review. Journal of Plant Nutrition, Philadelphia, v. 37, n. 6, p. 942-963, 2014.

AWAIS M. et al. Modeling the water and nitrogen productivity of sunflower using OILCROP-SUN model in Pakistan. Field Crops Research, Amsterdam, v. 205, n. 1, p. 67-77, 2017.

BATTISTI, D. S.; NAYLOR, R. L. Historical warnings of future food insecurity with unprecedented seasonal heat. Science, Washington, v. 323, n. 5911, p. 240-244, 2009.

CASTRO, C.; FARIAS, J. R. B. Ecofisiologia do girassol. In: LEITE, R. M. V. B. C.; BRIGHENTI, A. M.; CASTRO, C. (Eds.). Girassol do Brasil. Londrina: Embrapa Soja, 2005. cap. 9, p. 163-218.

CASSMAN, K. G. et al. Meeting cereal demand while protecting natural resources and improving environmental quality. Annual Review of Environment and Resources, Palo Alto, v. 28, n. 1, p. 315-358, 2003.

CORMIER, F. et al. Breeding for increased nitrogenuse efficiency: a review for wheat (T. aestivum L.) Plant Breeding, Hoboken, v. 135, n. 3, p. 255-278, 2016.

DALCHIAVON, F. C. et al. Características agronômicas e suas correlações em híbridos de girassol adaptados à segunda safra. Pesquisa Agropecuaria Brasileira, Brasília, v. 51, n. 11, p. 1806-1812, 2016.

GAO, Q. et al. Understanding yield response to nitrogen to achieve high yield and high nitrogen use efficiency in rainfed corn. Agronomy Journal, Madison, v. 104, n. 1, p. 165-168, 2012.

GARCÍA, L. J. et al. Evaluation of three simulation approaches for assessing yield of rainfed sunflower in a Mediterranean environment for climate change impact modelling. Climatic Change, Dordrecht, v. 124, n. 1, p. 147-162. 2014.

GARCÍA, L. J. et al. Yield response of sunflower to irrigation and fertilization under semi-arid conditions. Agricultural Water Management Amsterdam, v. 176, n. 2, p. 151-162, 2016.

HAN, M. et al. The genetics of nitrogen use efficiency in crop plants. Annual Review of Genetics, Palo Alto, v. 49, n. 3, p. 269-289, 2015.

LÓPEZ-BELLIDO, L. et al. Fertilizer nitrogen efficiency in durum wheat under rainfed Mediterranean conditions: Effect of split application. Agronomy Journal, Madison, v. 98, n. 1, p. 55-62, 2006.

MASCLAUX-DAUBRESSE, C. et al. Nitrogen uptake, assimilation and remobilization in plants: Challenges for sustainable and productive agriculture. Annals of Botany, Oxford, v. 105, n. 7, p. 1141-1157, 2010 .

MOHAMMADI, K. et al. Fertilization affects the agronomic traits of high oleic sunflower hybrid in different tillage systems. Industrial Crops and Products, Amsterdam, v. 44, n. 1, p. 446-451, 2013.

MOLL, R. H.; KAMPRATH, E. J.; JACKSON, W. A. Analysis and interpretation of factors which contribute to efficiency to nitrogen utilization. Agronomy Journal, Madison, v. 74, n. 3, p. 562564,1982

NASIM, W. et al. Correlation studies on nitrogen for sunflower crop across the agroclimatic variability. 
Environmental Science and Pollution Research, Heidelberg, v. 23, n. 4, p. 3658-3670, 2016.

NYIKAKO, J. et al. Genetic variation in nitrogen uptake and utilization efficiency in a segregating DH population of winter oilseed rape. Euphytica, Dordrecht, v. 199, n. 1, p. 3-11, 2014.

PAPATHEOHARI, Y. et al. Growth and yield of three sunflower hybrids cultivated for two years under Mediterranean conditions. Emirates Journal of Food and Agriculture, Abu Dhabi, v. 28, n. 2, p. 136-142, 2016.

RIAR, A.; COVENTRY, D. Nitrogen use as a component of sustainable crop systems. In: BHULLAR, G. S.; BHULLAR, N. K. (Eds.). Agricultural sustainability: Progress and prospects in crop research. London: Elsevier, 2013. v. 1 , cap. 4 , p. $63-76$.

RONDANINI, D.; SAVIN, R.; HALL, A. J. Dynamics of fruit growth and oil quality of sunflower (Helianthus annus L.) exposed to brief intervals of high temperature during achene filling. Field Crops Research, Amsterdam, v. 83, n. 1, p. 79 $-90,2003$.

ROUPHAEL, Y. et al. Leaf area estimation of sunflower leaves from simple linear measurements. Photosynthetica, Dordrecht, v. 45, n. 4, p. 306-308, 2007.

SADRAS, V. O. Yield and water-use efficiency of water- and nitrogen-stressed wheat crops increase with degree of co-limitation. European Journal of Agronomy, Amsterdam, v. 21, n. 4, p. 455-464, 2004.

SCHNEITER, A. A.; MILLER, L. F. Description of sunflower growth stages. Crop Science, Madison, v. 21, n. 6, p. 901-903, 1981.

SIELING, K.; KAGE, H. The potential of semidwarf oilseed rape genotypes to reduce the risk of $\mathrm{N}$ leaching. Journal of Agricultural Science, New York, v. 146, n. 1, p.77-84, 2008.

SKORIC, D. Achievements and future directions of sunflower breeding. Field Crops Research, Amsterdam, v. 30, n. 3, p. 231-270, 1992.

SNYDER, R. L. Hand calculating degree days. Agricultural and Forest Meteorology, Amsterdam, v. 35, n. 4 , p. 353-358, 1985.

SPOSARO, M. M.; CHIMENTI, C. A.; HALL, A. J. Root lodging in sunflower, variations in anchorage strength across genotypes, soil types, crop population densities and crop developmental stages. Field Crops Research, Amsterdam, v. 106, n. 2, p. 179186, 2008.

SZMIGIEL, A. et al. Efficiency of nitrogen fertilization in spring wheat. International Journal of Plant Production, Gorgan, v. 10, n. 4, p. 447456, 2016

VALVERDE, P. et al. Climate change impacts on rainfed agriculture in the Guadiana river basin (Portugal). Agricultural Water Management, Amsterdam, v. 150, n. 1, p. 35-45, 2015.

VOS, J.; VAN DER PUTTEN, P. E. L.; BIRCH, C. J. Effect of nitrogen supply on leaf appearance, leaf growth, leaf nitrogen economy and photosynthetic capacity in maize (Zea mayz L.) Field Crops Research, Amsterdam, v. 93, n. 1, p. 64-73, 2004. 